\title{
The Effects of Salt Loading on the Renin- Angiotensin Control of Blood Pressure in the Newborn Lamb
}

\author{
SHARON R. SIEGEL ${ }^{(24)}$ \\ Department of Pediatrics, UCLA Hospital and Clinics, Los Angeles, California, USA
}

\begin{abstract}
Summary
The renin-angiotensin system control of newborn blood pressure was studied in six sets of twin newborn lambs. The mean aortic blood pressure and plasma renin activity (PRA) was $79.6 \pm 0.96$ $\mathrm{mmHg}$ (mean and S.E.) and $6.88 \pm 0.83 \mathrm{ng} / \mathrm{ml} / \mathrm{h}$ in the chronically salt-loaded lambs $(10 \mathrm{mEq} / \mathrm{kg} / \mathrm{day}$ for 5 days $) ; 86.16 \pm 1.8 \mathrm{mmHg}$ $(P<0.001)$ and $20.48 \pm 2.46 \mathrm{ng} / \mathrm{ml} / \mathrm{h}(P<0.001)$, respectively in the control lambs. PRA and \% change after angiotensin 11 blockade with saralasin was greater in the control lambs, $181.5 \pm 6.09$ $\mathrm{ng} / \mathrm{ml} / \mathrm{h}$ and $780 \%$ than in the chronically salt-loaded lambs, 40 \pm 10.47 and $480 \%, P<0.001$. Blood pressure decreased $10 \mathrm{mmHg}$ only in the control lambs, $P<0.001$. An angiotensin 11 dose of $0.25 \mu \mathrm{g} / \mathrm{kg} / \mathrm{min}$ increased blood pressure $32 \pm 3.1 \mathrm{mmHg}$ in control mambs, and $0.10 \mu \mathrm{g} / \mathrm{kg} / \mathrm{min}$ increased blood pressure 32 $\pm 3.2 \mathrm{mmHg}$ in acutely salt-loaded $(10 \mathrm{mEq} / \mathrm{kg}$ in $20 \mathrm{ml} 5 \%$ dextrose/water) lambs. PRA and mean aortic blood pressure decreased in the acutely salt-loaded lambs from $22.3 \pm 3.0 \mathrm{ng} / \mathrm{ml} /$ $h$ and $86.6 \pm 1.0 \mathrm{mmHg}$ to $11.3 \pm 1.1$ and $76.4 \pm 0.8, P<0.01$, respectively. These data show that sodium loading will suppress the basal renin-angiotensin system levels, and mean aortic blood pressure; decrease the hypotensive and PRA responses to saralasin; and increase the pressor responsiveness to angiotensin 11.
\end{abstract}

\section{Abbreviations}

$D / W$, dextrose/water

PRA, plasma renin activity

Blood pressure is under volume and vasoconstrictive control. In the normal newborn lamb, basal blood pressure is maintained under the vasoconstrictor control of the renin-angiotensin system (19). Pressor responsiveness to angiotensin 11 is decreased compared to the ewe (18). These altered responses may be secondary to the very high renin-angiotensin levels present in the newborn lamb (20).

Blood pressure control and the renin-angiotensin system are both affected by sodium $(8,10,11)$. The purpose of this study was to determine the effects of acute and chronic salt loading on the renin-angiotensin system and blood pressure control in the newborn lamb.

\section{MATERIALS AND METHODS}

Six sets of twin newborn lambs 7-14 days (7-9 kg) and 14-21 days $(11-13 \mathrm{~kg})$ were studied for each experiment. The nursing lambs with their mothers were obtained from the vivarium. Polyvinyl catheters were inserted into the femoral artery and vein under local anesthetic ( $1 \%$ lidocaine). The animals were restrained on a specially constructed board, so that they were nonstressed and warm, and studied 2 days after catheter placement.

Experiment $1 . \mathrm{NaCl}(10 \mathrm{mEq} / \mathrm{kg}$ in $20 \mathrm{ml} \% \mathrm{D} / \mathrm{W})$ was infused over $60 \mathrm{~min}$ in one of each set of twin lambs 7-14 days of age.
Serial doses of angiotensin $11(0.025,0.5,0.1$, and $0.25 \mu \mathrm{g} / \mathrm{kg} /$ $\mathrm{min}$ ) were infused for $15 \mathrm{~min}$ each into the salt-loaded and control lambs. Blood samples for PRA were drawn before and 55 and 60 min after the $\mathrm{NaCl}$ infusion. Mean aortic blood pressure was monitored continuously.

Experiment 2. $\mathrm{NaCl}(10 \mathrm{mEq} / \mathrm{kg} /$ day in $50 \mathrm{ml} 5 \% \mathrm{D} / \mathrm{W})$ was infused slowly over $2 \mathrm{~h}$ for 5 days into one of each set of twin lambs 14-21 days of age. On the 5th day, two baseline blood samples were drawn 10 minutes apart for determination of PRA and plasma sodium. These were followed by a 30-min infusion of saralasin acetate $(10 \mu \mathrm{g} / \mathrm{kg} / \mathrm{min})$. Repeat blood samples were drawn at 5,15 , and $30 \mathrm{~min}$ after the start of the infusion, and 30 min after stopping. Less than $3 \%$ of the blood volume was removed and the blood was replaced with $0.25 \mathrm{~N}$ saline. Mean aortic blood pressure was monitored continuously with a Statham transducer and Gould blood pressure recorder.

For measurement of PRA, the blood samples were collected in KEDTA $(150 \mu \mathrm{g} / \mathrm{ml}$ whole blood) at room temperature. To 1.0 $\mathrm{ml}$ of plasma, $10 \mu \mathrm{l}$ of $6.6 \mathrm{~g} / 100 \mathrm{ml} 8-\mathrm{OH}$ quinoline, $10 \mu \mathrm{l}$ of $10 \mathrm{~g} /$ $100 \mathrm{ml} \beta$-mercaptoethanol and $10 \mu \mathrm{l}$ of $3 \mathrm{~g} / 100 \mathrm{ml} o$-phenanthroline were added to inhibit converting enzyme and angiotensinase. Twenty-five $\mu \mathrm{l}$ of $4.0 \mathrm{M}$ Tris-phosphate-Tris maleate buffer $\mathrm{pH}$ 6.2 was added to reach a $\mathrm{pH}$ of 6.5 for maximal generation of angiotensin 1 in sheep blood. The blood was divided into two equal aliquots; one aliquot for a blank (frozen) and the other aliquot for generation of angiotensin 1 at $37^{\circ} \mathrm{C}$ for $1 \mathrm{~h}$. PRA (generated angiotensin 1) was measured by radioimmunoassay (7). Plasma renin concentration was measured by adding renin substrate according to the method of Skinner (17) to the procedure for maximal generation of angiotensin 1. Plasma sodium was measured by flame photometer.

Statistics were measured by paired $t$ test.

\section{RESULTS}

Table 1 shows the effects of acute salt loading on the pressor responsiveness to different concentrations of angiotensin 11 in the newborn lamb. Salt loading increases responsiveness to the different concentrations of angiotensin $11(0.025, .05$, and $0.1 \mu \mathrm{g} / \mathrm{kg} /$ min, $P<0.001)$. The $0.25 \mu \mathrm{g} / \mathrm{kg} / \mathrm{min}$ dose is not statistically different. The normal (no change) and salt-loaded lamb (15 $\mathrm{mmHg}$ ) response to the $0.025 \mu \mathrm{g} / \mathrm{kg} / \mathrm{min}$ angiotensin 11 was less than in the ewe $(33 \mathrm{mmHg})(P<0.001)$.

Table 2 shows the effects of acute salt loading on plasma renin activity and mean aortic blood pressure. PRA and mean aortic blood pressure both decreased $(P<0.01)$ after acute salt loading expansion of the extracellular fluid volume.

Table 3 shows the PRA and mean aortic blood pressure to chronic salt loading and the angiotensin 11 blocker (saralasin acetate). Basal PRA and mean aortic blood pressure were suppressed $(P<0.001)$ with chronic salt loading. The PRA and blood pressure responsiveness to saralasin was decreased in the saltloaded lambs $(P<0.001)$. Basal PRA is $1.7 \pm 0.1 \mathrm{ng} / \mathrm{ml} / \mathrm{h}$ (mean and S.E. $),(n=6)$ in the normal ewe. 
Table 1. The effects of acute salt loading on pressor responsiveness to angiotensin 11 in the newborn lamb ${ }^{1}$

\begin{tabular}{llrrr}
\hline & $n$ & Control lambs & $\begin{array}{c}\text { Salt-Loaded } \\
\text { lambs }\end{array}$ & $P$ value \\
\hline $\begin{array}{l}\text { Mean aortic blood pressure } \\
\text { (mmHg) }\end{array}$ & 6 & $86.7 \pm 1.0$ & $76.6 \pm 0.9$ & \\
Change in mean blood & 6 & & & \\
pressure (mmHg) after fol- & & & \\
lowing dosages of angio- & & & \\
tensin 11 & & & \\
$0.025 \mu \mathrm{g} / \mathrm{kg} / \mathrm{min}$ & No change & $15 \pm 2.5$ & $<0.001$ \\
$0.05 \mu \mathrm{g} / \mathrm{kg} / \mathrm{min}$ & No change & $21 \pm 3.0$ & $<0.001$ \\
$0.10 \mu \mathrm{g} / \mathrm{kg} / \mathrm{min}$ & $10 \pm 2.1$ & $32 \pm 3.2$ & $<0.001$ \\
$0.25 \mu \mathrm{g} / \mathrm{kg} / \mathrm{min}$ & $32 \pm 3.1$ & $41 \pm 3.4$ & \\
\hline
\end{tabular}

${ }^{1}$ Mean and S.E.

${ }^{2}$ Received ( $10 \mathrm{mEq} / \mathrm{kg}$ in $20 \mathrm{ml} / \mathrm{kg} 5 \%$ dextrose/water) over $60 \mathrm{~min}$.

Table 2. The effects of acute salt loading on plasma renin activity and blood pressure in the newborn lamb ${ }^{1}$

\begin{tabular}{|c|c|c|c|c|}
\hline \multirow[b]{2}{*}{ Twin lambs } & \multirow[b]{2}{*}{$n$} & \multirow{2}{*}{$\begin{array}{l}\text { Baseline plasma renin } \\
\text { activity }(\mathrm{ng} / \mathrm{ml} / \mathrm{h})\end{array}$} & \multicolumn{2}{|c|}{ Time (min) of infusion } \\
\hline & & & 55 & 60 \\
\hline Control lambs & 6 & $23.4 \pm 2.1$ & $22.4 \pm 2.3$ & $21.5 \pm 3.1$ \\
\hline $\begin{array}{l}\text { Salt-loaded }{ }^{2} \\
\text { lambs }\end{array}$ & 6 & $22.3 \pm 3.0$ & $11.3 \pm 1.1^{3}$ & $11.4 \pm 2.1$ \\
\hline Twin lambs & $n$ & $\begin{array}{l}\text { Mean aortic blood } \\
\text { pressure }(\mathrm{mmHg})\end{array}$ & 55 & 60 \\
\hline Control lambs & 6 & $87.3 \pm 0.7$ & $86.4 \pm 0.6$ & $86.7 \pm 1.0$ \\
\hline $\begin{array}{l}\text { Salt-loaded }{ }^{2} \\
\text { lambs }\end{array}$ & 6 & $86.6 \pm 1.0$ & $76.4 \pm 0.8^{3}$ & $76.6 \pm 0.9$ \\
\hline
\end{tabular}

\footnotetext{
${ }^{1}$ Mean and S.E.

${ }^{2}$ Received $10 \mathrm{mEq} / \mathrm{kg}$ in $20 \mathrm{ml} / \mathrm{kg} 5 \%$ dextrose/water.

${ }^{3} P<0.01$.
}

Table 3. Effects of increased sodium intake on the responsiveness to saralasin in the newborn lamb ${ }^{1}$

\begin{tabular}{lcccc}
\hline & & \multicolumn{2}{c}{ Twin lambs } & \\
\cline { 2 - 4 } & & $\begin{array}{c}\text { Control } \\
\text { lambs }\end{array}$ & $\begin{array}{c}\text { Salt-loaded } \\
\text { lambs }\end{array}$ & $P$ value \\
\hline $\begin{array}{c}\text { Baseline plasma renin } \\
\text { activity (ng/ml/h) }\end{array}$ & 6 & $20.48 \pm 2.46$ & $6.88 \pm 0.83$ & $<0.001$ \\
$\begin{array}{c}\text { PRA responsiveness to } \\
\text { saralasin (ng/ml/h) }\end{array}$ & 6 & $181.5 \pm 6.09$ & $40.0 \pm 10.47$ & $<0.001$ \\
$\begin{array}{l}\text { Plasma Na (mEq/liter) } \\
\text { Baseline mean aortic }\end{array}$ & 6 & $139.5 \pm 0.19$ & $145.8 \pm 0.30$ & $<0.001$ \\
$\quad$ blood pressure & $86.16 \pm 1.8^{3}$ & $79.5 \pm 0.96$ & $<0.001$ \\
$\begin{array}{c}\text { (mmHg) } \\
\text { Blood pressure respon- } \\
\text { siveness to saralasin } \\
\text { (mmHg) }\end{array}$ & 6 & $75.66 \pm 1.76^{3}$ & $78.0 \pm 1.03$ & \\
\hline
\end{tabular}

\footnotetext{
${ }^{1}$ Mean and S.E.

${ }^{2}$ Received $\mathrm{NaCl} 10 \mathrm{mEq} / \mathrm{kg} /$ day for 5 days.

${ }^{3}$ Baseline vs blood pressure responsiveness to saralasin $(P<0.001)$.
}

\section{DISCUSSION}

The renin-angiotensin system levels are high in the newborn human $(6,13,16)$, lamb (20), and canine puppy (5). These high renin-angiotensin levels contribute to basal control of blood pressure (19) and possibly decreased pressor responsiveness to angiotensin 11 (18) in the newborn lamb.

The renin-angiotensin system and blood pressure are both affected by sodium $(8,10,11)$. The sodium dependent regulatory mechanisms for renin is functional in the newborn lamb (20) and human $(21,22)$.
In Table 1, acute extracellular expansion with sodium loading increased pressor responsiveness to angiotensin $11(0.025-0.1 \mu \mathrm{g} /$ $\mathrm{kg} / \mathrm{min})(P<0.001)$. The pressor responsiveness to a $0.025 \mu \mathrm{g} /$ $\mathrm{kg} / \mathrm{min}$ was less in both the normal and salt-loaded lamb than in the ewe $(P<0.001)$. Pressor responsiveness to angiotensin 11 varies with sodium balance (10) and plasma angiotensin 11 levels (3). The PRA levels (Table 2) were suppressed from $22.3 \pm 3.0$ $\mathrm{ng} / \mathrm{ml} / \mathrm{h}$ to $11.3 \pm 1.1, P<0.01$. To determine whether or not it was the increased sodium or decreased PRA which was responsible for increasing pressor responsiveness, further study with a converting enzyme blocker to lower the high endogenous renin-angiotensin 11 levels in the newborn lamb will be needed.

The fall in mean aortic blood pressure (Table 2) from $86.6 \pm$ $1.0 \mathrm{mmHg}$ to $76.4 \pm 0.8(P<0.01)$, which accompanied the fall in PRA, further supports the important role of the renin-angiotensin system in the control of basal blood pressure in the newborn lamb. Acute volume expansion ( $10 \mathrm{mEq} / \mathrm{kg}$ in $20 \mathrm{ml} 5 \% \mathrm{D} / \mathrm{W})$ in normal man or animal results in either no change in blood pressure $(4,9)$ or possibly an increase in blood pressure instead of the decrease seen in the normal newborn lamb.

Chronic salt loading ( $10 \mathrm{mEq} / \mathrm{kg} /$ day) for 5 days suppressed (Table 3) PRA from $20.8 \pm 2.4 \mathrm{ng} / \mathrm{ml} / \mathrm{h}$ to $6.8 \pm 0.8, P<0.001$, in the newborn lamb. The PRA in the salt-loaded lamb is still greater than in a normal ewe, $1.7 \pm 0.1 \mathrm{ng} / \mathrm{ml} / \mathrm{h} P<0.001$ ). This suggests that additional factors are responsible for the high basal renin-angiotensin system levels in the newborn.

PRA increased from $20.4 \pm 2.4 \mathrm{ng} / \mathrm{ml} / \mathrm{h}$ to $181.5 \pm 6.0,780 \%$, with saralasin in the control lamb. This is also a maximal response of plasma renin concentration with added renin substrate versus available endogenous renin substrate in the newborn lamb. The PRA increase from $6.8 \pm 0.8 \mathrm{ng} / \mathrm{ml} / \mathrm{h}$ (Table 3) to $40.0 \pm 10.4$, $480 \%$, in the salt-loaded lamb was less than in the control lamb $(P<0.001)$. The hypotensive response in the normal lamb from $86.1 \pm 1.8 \mathrm{mmHg}$ to $75.6 \pm 1.7(P<0.001)$ was not present in the salt-loaded lamb.

In man $(8,14)$ or $\operatorname{dog}(11)$ on a normal or sodium replete diet, saralasin will either have no effect on PRA and blood pressure, or have an agonistic effect and decrease PRA and increase blood pressure; therefore, the salt-loaded lamb demonstrated a blood pressure response similar to normal man, and a lessened PRA antagonistic response. On a low sodium diet, saralasin will have an antagonistic effect in man (8) and $\operatorname{dog}(12)$ and decrease blood pressure and increase PRA. The normal newborn lamb gives a similar antagonistic response as an adult on a low sodium diet. To determine whether or not it is the sodium state or high reninangiotensin levels in the normal newborn responsible for the saralasin response, further study with a converting enzyme blocker to lower the high endogenous renin-angiotensin 11 levels in the newborn lamb will be needed.

Another possible cause for the hypotensive and maximal PRA response to saralasin in the newborn is the increased neurohumoral tone (1). It has been shown in hypertensive man that propranolol (15) will lower the hypotensive response, suggesting that the angiotensin feedback-suppression mechanism for inhibiting renin release is functionally located proximal to beta-adrenergic receptors mediating renin release.

Angiotensin 11 levels are related to systolic blood pressure in the newborn human (2). If blood pressure control in the human is similar to the lamb, then the sodium intake (with its effect on renin-angiotensin system levels) will play an important role in basal blood pressure control and blood pressure responsiveness in the newborn. The nursing lamb receives a low sodium $(6-7 \mathrm{mEq} /$ liter) intake as does the human.

\section{REFERENCES AND NOTES}

I. Assali, N. S., Brinkman 111 [sic]. C. R., Woods, J. R., Dandavino, A., and Nuwayhid, B.: Development of neurohumoral control of fetal, neonatal, and adult cardiovascular function. Amer. J. Obs. Gynecol.. 129: 748 (1977).

2. Broughton-Pipkin, F., and Symonds, E. M.: Factors affecting angiotensin 11 concentrations in the human infant at birth. Clin. Sci., 52: 449 (1977).

3. Chinn, R. H. and Dusterdieck, G.: The response of blood pressure to angiotensin 
11: Relation to plasma concentrations of renin and angiotensin 11. Clin. Sci., 42: 489 (1972).

4. Churchill, P. C., Churchill, M. C., and McDonald, F. D.: Effects of saline and mannitol on renin and the distal tubule $\mathrm{Na}$ in rats. Circ. Res., 45: 786 (1979).

5. Drukker, A., Goldsmith, D. I., Spitzer, A., Edelman, C. M., Jr., and Blaufox, D. The renin-angiotensin system in newborn dogs: developmental patterns and response to acute salt loading. Pediatr. Res., 14: 304 (1980).

6. Godard, C., Gaillard, R., and Vallotton, M. B.: The renin-angiotensin-aldosterone system in mother and fetus at term. Nephron, 17: 353 (1976).

7. Haber, E., Koerner, T., Page, L. B., Kliman, B., and Purnode, A.: Application of a radioimmunoassay for angiotensin 1 in normal human subjects. J. Clin. Endocrinol. Metab., 29: 1349 (1969).

8. Hata, T., Ogihara, T., Mikami, H., Nakamuru, M., Mandai, T., and Kumahara, $Y .:$ Effects of two angiotensin 11 analogues on blood pressure, plasma aldosterone concentration, plasma renin activity, and creatinine clearance in normal subjects on different intakes. Eur. J. Clin. Pharmacol., I8: 295 (1980).

9. Hesse, B., Nielsen, I., Ring-Larsen, H., and Hansen, J. F.: The influence of acute blood volume changes on plasma renin activity in man. Scand. J. Clin. Lab. Invest., 38: 155 (1978).

10. Hollenberg, N. K., Chenitz, W. R., Adams, D. F., and Williams, G. H.: Reciprocal influence of salt intake on adrenal glomerulosa and renal vascular responses to angiotensin 11 in normal man. J. Clin. Invest., 54: 34 (1974).

11. Johnson, J. A. and Davis, J. O.: Angiotensin 11 : important role in the maintenance of arterial blood pressure. Science, 179: 906 (1973).

12. Johnson, J. A. and David, J. O.: Effects of a specific competitive antagonist of angiotensin 11 on arterial pressure and adrenal steroid secretion in dogs. Circ. Res., 32: 159 (1973).

13. Kotchen, T. A., Strickland, A. L., Rice, T. W., Walters, D. R.: A study of the renin-angiotensin system in newborn infants. J. Pediatr. 80: 938 (1972).

14. Noth, R. H., Tan. S. Y.. and Mulrow, P. J.: Effects of angiotensin 11 blockade by saralasin in normal man. J. Clin. Endocrinol. Metab., 45: 10 (1972).

15. Pettinger, W. A. and Mitchell, H. C.: Renin release, saralasin, and the vasodilatorbeta-blocker drug interaction in man. N. Engl. J. Med., 292: 1214 (1975).

16. Pohlova, I., Janovsky, M., and Jelinek, D.: Plasma renin activity in the newly born and in young infants. Physiol. Bohenoslov., 22: 233 (1973).

17. Skinner, S. L.: Improved assay methods for renin concentration and activity in human plasma. Circ. Res., 22: 391 (1967).

18. Siegel, S. R.: Decreased vascular and increased adrenal and renal sensitivity to angiotensin 11 in the newborn lamb. Circ. Res., $48: 34$ (1981).

19. Siegel, S. R. and Fisher, D. A.: The effects of angiotensin 11 blockade and nephrectomy on the renin-angiotensin-aldosterone system in the newborn lamb. Pediatr. Res., 13: 603 (1979).

20. Siegel, S. R. and Fisher, D. A.: The renin-angiotensin-aldosterone system in the newborn lamb: response to furosemide. Pediatr. Res., 11: 837 (1977).

21. Sulyok, E., Nemeth, M., Tenyi, I., Csaba, I., Gyory, E., Ertl, T., and Varga, F.: Postnatal development of renin-angiotensin-aldosterone system (RAAS) in relation to electrolyte balance in premature infants. Pediatr. Res., 13: 817 (1979).

22. Sulyok, E., Varga, F., Nemeth, M., Tenyi., I. F., Csaba, F., Ertl, T., and Gyory, E.: Furosemide-induced alterations in electrolyte status, the function of the renin-angiotensin-aldosterone system, and the urinary excretion of prostaglandins in the newborn infant. Pediatr. Res., 14: 765 (1980).

23. This work is supported by Grant HD 13910 from the National Institutes of Child Health and Human Development, National Institutes of Health, Bethesda, Maryland.

24. Requests for reprints should be addressed to: Dr. Sharon R. Siegel, UCLA Hosp. \& Clinics, Dept. of Pediatrics, 22-404 MDCC, Los Angeles, California 90024. 25. Received for publication August 3, 1981.

26. Accepted for publication August 12, 1982. 